\title{
Managing Sources and Sinks of Greenhouse Gases in Australia's Rangelands and Tropical Savannas
}

\author{
Garry D. Cook, ${ }^{1}$ Richard J. Williams, ${ }^{2}$ Christopher J. Stokes, ${ }^{3}$ Lindsay B. Hutley, ${ }^{4}$ \\ Andrew J. Ash, ${ }^{5}$ and Anna E. Richards ${ }^{6}$ \\ Authors are ${ }^{1}$ Principal Research Scientist, ${ }^{2}$ Senior Principal Research Scientist, and ${ }^{6}$ Postdoctoral Fellow, CSIRO Sustainable Ecosystems, PMB 44, \\ Winnellie NT 0822, Australia; ${ }^{3}$ Senior Research Scientist, CSIRO Sustainable Ecosystems, PMB PO, Aitkenvale Q 4814, Australia; ${ }^{4}$ Associate Professor, \\ School of Environmental and Life Sciences and School of Environmental Research, Charles Darwin University, Darwin, NT 0909, Australia; and ${ }^{5}$ Senior \\ Principal Research Scientist, CSIRO Sustainable Ecosystems, Level 3, 306 Carmody Rd, St Lucia Q 4067, Australia.
}

\begin{abstract}
Rangelands and savannas occupy $70 \%$ of the Australian continent and are mainly used for commercial grazing of sheep and cattle. In the center and north, where there are extensive areas of indigenous land ownership and pastoral production is less intensive, savanna burning is frequent. Greenhouse gas emissions from rangelands have been overwhelmingly from land clearing and methane production by livestock. Reductions in the rate of land clearing have substantially reduced Australia's greenhouse gas emissions, but these have been controversial with the reduced potential pasture production being of concern to many land managers. Reductions in direct livestock emissions are possible through manipulation of the genetics, rumen flora, or diet of animals. However, the greatest potential benefit is a whole-property approach with improved animal husbandry and attention to other aspects of property management such as fossil fuel consumption. Focus on emissions per unit of land area is likely to have other ecological benefits for land condition and to capture the effects of changes in carbon stocks in vegetation and soils. In much of northern and central Australia, changes in settlement patterns have led to more frequent and intense fires than under indigenous management regimes before European settlement. The implementation of more benign regimes of savanna burning has great potential benefit for greenhouse abatement, biodiversity, and livelihoods of indigenous people in remote settlements.
\end{abstract}

\section{Resumen}

Los pastizales naturales y las sabanas ocupan un $70 \%$ del continente Australiano y se utilizan mayormente para el pastoreo comercial de ovinos y bovinos. En el centro y norte del continente, donde hay superficies extensas de tierras aborígenes y la producción pastoril es menos intensiva, la quema de sabanas es frecuente. La emisión de gases invernadero de los pastizales naturales ha provenido mayormente de la modificación de la vegetación mientras que la producción de metano ha provenido mayormente del ganado. Reducciones en la tasa de modificación de la vegetación han disminuido sustancialmente la emisión de gases invernadero de Australia, pero dichos cambios han sido controversiales por la reducción en el potencial productivo de los pastizales que preocupa a muchos ganaderos. La reducción directa de las emisiones del ganado son posibles a través de la manipulación de la genética animal, de la flora ruminal o de la dieta animal. El mayor beneficio potencial, no obstante, se obtendría a través de un enfoque integral que abarque toda la propiedad con un mejoramiento en el manejo animal y la atención a otros aspectos del manejo de la propiedad tales como el consumo de combustibles fósiles. El énfasis sobre las emisiones producidas por unidad de superficie de la tierra tendrá seguramente otros beneficios ecológicos sobre la condición de las tierras y la captura de los efectos del cambio de los stocks de carbono en la vegetación y los suelos. En gran parte del norte y centro de Australia, cambios en los patrones de asentamiento han provocado fuegos más frecuentes y de mayor intensidad que los que ocurrían durante el régimen de manejo aborigen de la tierra previo al asentamiento europeo. La implementación de regímenes más benignos de quema de sabanas posee grandes beneficios potenciales para la reducción de gases de invernadero, la biodiversidad y la viabilidad económica de los asentamientos remotos de poblaciones aborígenes.

Key Words: burning, carbon, deforestation, emissions, fire, livestock, vegetation thickening

\section{INTRODUCTION}

Australia's rangelands and savannas, which occupy most of the continent, play an important role in the country's carbon $(\mathrm{C})$

\footnotetext{
This publication was made possible through support provided to the Global Livestock Collaborative Research Support Program by the Office of Agriculture, Bureau for Economic Growth, Agriculture and Trade, United States Agency for International Development under terms of Grant No. PCE-G-00-98-00036-00. The opinions expressed herein are those of the author(s) and do not necessarily reflect the views of the USAID.

Correspondence: Dr Garry Cook, PMB 44, Winnellie, NT 0822, Australia. Email: Garry.Cook@ CSIRO.au

Manuscript received 10 April 2008; manuscript accepted 25 February 2009.
}

balance as a result of interactions between climate, vegetation, soils, fire, and grazing. If the net greenhouse gas (GHG) emissions of rangelands are to be effectively reduced, management strategies not only need to take a whole-of-system view of GHG budgets, but must also consider potential trade-offs and synergies with other ecosystem services that rangelands provide. In this review we explore the land management options that could meet these requirements and some of the challenges in formulating effective GHG management strategies for Australia's rangelands and savannas.

Grazing is the dominant land use in Australia's rangelands and savannas. There are no native ungulates in Australia, and 
the first exotic, domesticated ungulates were introduced by European settlers in 1788. However, pastoralism did not become well established in parts of northern Australia until less than a century ago. Yet in 2005 Australia was home to more than 100 million sheep and 27 million cattle (Trewin 2007). Domestic and feral ungulates are now directly responsible for about $11 \%$ of Australia's accountable $\mathrm{CO}_{2}$ equivalent $\left(\mathrm{CO}_{2}\right.$-e) emissions per year through enteric fermentation and the deposition of urine and feces (National Greenhouse Gas Inventory Committee 2005). Indirect emissions from land management practices-principally deforestation-to support commercial pastoral production contributed double the direct emissions from livestock in 1990 but have since been declining (National Greenhouse Gas Inventory Committee 2005). Fire regimes have also been greatly altered since the arrival of Europeans and the spread of pastoralism, but fires in rangelands account for about $1-3 \%$ of Australia's accountable GHG emissions.

In this paper we give a brief background to the natural environment and management of the Australian rangelands and tropical savannas, describe in greater detail the trends in GHG emissions from rangeland sources, and discuss approaches that have been considered to reduce GHG emissions in Australia's rangelands and tropical savannas. We conclude by considering the implications for future research and the trade-offs between GHG objectives and other environmental and livelihood considerations.

\section{BIOPHYSICAL OVERVIEW}

Australia's low relief, tectonic stability, and virtual absence of glaciation have produced extensive areas of deeply weathered and infertile landscapes dating from the Tertiary Period (McKenzie et al. 2004). Suitable areas for cropping are largely restricted to the more mesic southeast, east, and southwest of the Australian continent, with the rest of the country being sparsely populated and used mainly for low-intensity grazing of livestock. Rangelands and savannas cover approximately $70 \%$ of mainland Australia (Graetz et al. 1988) and consist of variously distributed grasslands, shrublands, woodlands, and savannas (Fig. 1).

The climate in arid Australia is generally unpredictable and extreme, with low and variable rainfall, high temperatures, and high rates of evaporation (Linacre and Hobbs 1977). The shrublands and woodlands of southern Australia have a Mediterranean climate, whereas central Australia is arid without a strong seasonal signal in its rainfall. The northern half of Australia is characterized by a tropical semiarid climate with more predictable rainfall (particularly monsoonal rains in the far north), $70 \%$ of which falls in summer between November and March.

More than $40 \%$ of the continent is covered by dunefields and relictual dust mantles (Butler and Churchward 1983; McKenzie et al. 2004). About half of this region is covered by Spinifex grasslands (Triodia spp.), which have very low palatability. Unlike arid grasslands on other continents, Spinifex grows to form a substantial hummock, allowing fires to spread in the desert. Extensive fires spread across central Australia following years with good rains (Russell-Smith et al. 2007). The tropical

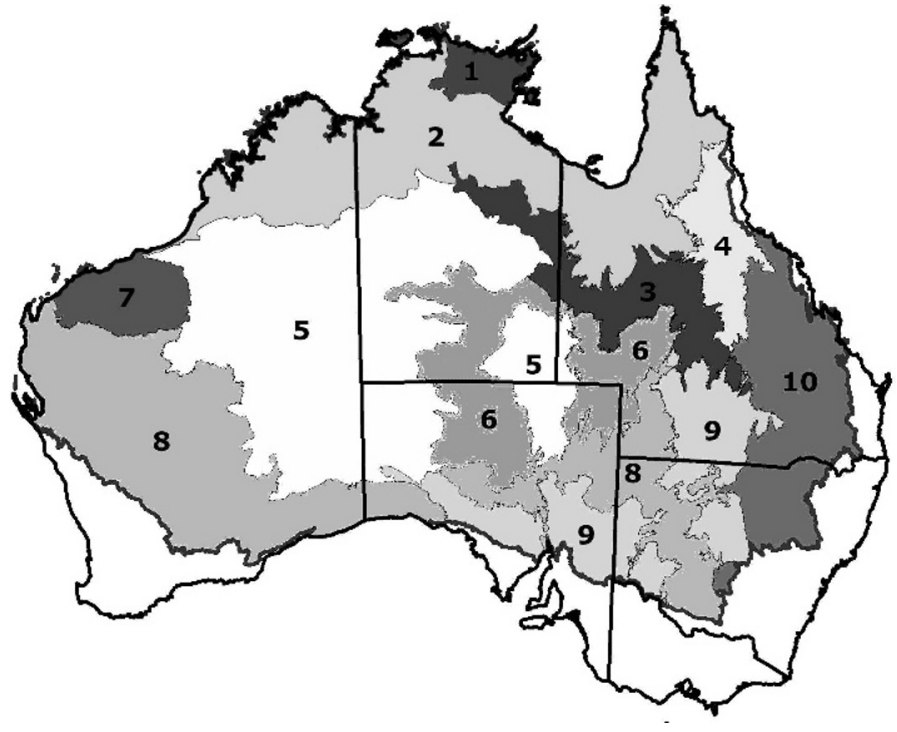

Figure 1. Map of Australia's rangelands and savannas. 1, Arnhemland and Tiwi Islands: eucalyptus savannas; 2, tropical eucalyptus savannas; 3, Mitchell grass (Astrebla spp.) downs; 4, Einsleigh and desert uplands eucalyptus savannas; $\mathbf{5}$, arid deserts dominated by Spinifex (Triodia spp.) hummock grasslands; 6, chenopod and hummock grasslands; 7 , Pilbara hummock grasslands; 8 and $\mathbf{9}$, acacia and eucalyptus woodlands and shrublands; 10, highly modified rangelands dominated by exotic grasses. Source: Fisher et al. (2004).

savannas of the north cover about one-third of the continent. Highly productive grasses of low palatability and nitrogen content dominate the understory in much of the savanna woodlands. These grasses are only lightly grazed and contribute to extensive savanna fires during the northern dry season. The most productive native pastures are generally restricted to riparian floodout areas, deeper red loams, and areas of cracking clay soils in either basaltic landscapes or those with clay-rich sedimentary rocks or covered with fine alluvium. Stafford-Smith and Morton (1990) and Ludwig et al. (1997) provide more detailed descriptions of the variation in landscape form and function in arid rangelands, and Williams et al. (2001) and Woinarski et al. (2005) provide more detail for the tropical savannas.

\section{LAND MANAGEMENT OVERVIEW}

Before European colonization, Australian indigenous people used fire to manage landscapes across the continent (Bowman 1998), and much of that in ways that would be classed as prescribed burning of savannas under the revised 1996 Intergovernmental Panel on Climate Change guidelines for national GHG inventories (Intergovernmental Panel on Climate Change 1996). The traditional practices ceased or were severely disrupted as European settlement and commercial pastoralism spread across the continent. Only in Australia's central and northern rangelands, where cattle stocking rates are very low and much land is owned by indigenous people under a variety of tenures, do traditional savanna burning practices remain. But even here, with much of the land depopulated as people 
Table 1. Accountable greenhouse gas emissions from Australian rangelands. Most but not all of these emissions derive from rangelands. ${ }^{1}$

\begin{tabular}{lccc}
\hline & \multicolumn{3}{c}{ Net emissions $\left(\mathrm{Mt} \mathrm{CO}_{2}-\mathrm{e} \cdot \mathrm{yr}^{-1}\right)$} \\
\cline { 2 - 4 } \multicolumn{1}{c}{ Sector } & 1990 & Range 1991-1994 & 2005 \\
\hline Land use change (deforestation) & 128.9 & 106.1 to 46.4 & 53.3 \\
Land use change (afforestation) & 0 & -0.5 to -17.8 & -19.6 \\
Livestock (enteric fermentation and & & & \\
$\quad$ manure) & 65.9 & 61.6 to 66.1 & 62.1 \\
Savanna burning & 6.6 & 6.1 to 15.8 & 8.6 \\
\hline
\end{tabular}

${ }^{1}$ Source: National Greenhouse Gas Inventory Committee 2005.

moved to larger, permanent settlements, fire management has undergone profound changes since the arrival of Europeans (Russell-Smith et al. 2003c, 2007). Anthropogenic ignition sources remain dominant in the north and arid center, but with less intensive indigenous management, and the resulting fires have trended toward being much larger and more intense (Russell-Smith et al. 2003a, 2007).

Unlike much of the world's rangelands, large areas of the Australian rangelands are occupied by corporate pastoralists, comprising both publicly owned companies and private operators (Bentley et al. 2008). Most of Australia's rangeland is publicly owned with commercial grazing operating under lease agreements with state governments. Ownership of rangelands and savannas by indigenous Australians is largely restricted to the north and center of the continent. Property sizes vary from thousands of square kilometers in the north and center, to small and sometimes subeconomic enterprises adjacent to urban areas and cropping lands in the east and south.

Considerable effort has been invested in the last century through government policy and scientific research to develop and increase the productivity of Australia's rangelands. This investment was based on the considerable success in increasing livestock production in southern Australia through the application of phosphate fertilizer to introduced pasture grasses and legumes. Pasture improvement had been the great hope for the rangelands, with Australian pasture agronomists scouring the world for exotic pasture species to introduce (Cook and Dias 2006). To support this development, the 10 -yr average rate of land clearing in 1990 was more than $5000 \mathrm{~km}^{2} \cdot \mathrm{yr}^{-1}$ (National Greenhouse Gas Inventory Committee 1994). In 1990 such deforestation accounted for nearly one-quarter of Australia's accountable GHG emissions, with more than $80 \%$ of that coming from land clearing in Queensland (National Greenhouse Gas Inventory Committee 2007). Increasing restrictions on land clearing have created GHG benefits, but the opportunity costs to individual enterprises have been the subject of considerable controversy (Rolfe et al. 2000; Climate Institute 2006).

\section{GHG FLUXES}

GHG emissions from Australian rangelands derive from three main sources: land-use change and land management, livestock, and savanna burning. Most of the Australian land-use change since 1990 has been deforestation of Eucalyptus- dominated woodlands and savannas to increase pastoral production in rangelands. In 1990 the $\mathrm{CO}_{2}$-e emissions from deforestation accounted for double those directly from livestock and about 20 times those from savanna burning (Table 1). Since then the rate of land clearing has decreased so that the annual emissions in 2005 were about two-thirds those from livestock. Carbon sequestration from accountable afforestation has steadily increased over that period so that, by 2005, the C sink from afforestation represented more than onethird of the $\mathrm{CO}_{2}$-e emissions from deforestation (Table 1).

Grazing land management and degradation of Australia's grazing lands through overstocking would have also contributed to Australia's GHG emissions since 1990, particularly through loss of soil C pools (Baker et al. 2000). However, these GHG fluxes are currently not accountable under Australia's National Greenhouse Gas Inventory.

Direct emissions of GHGs from livestock derive from both enteric fermentation and manure management, with the former accounting for about 30 times the $\mathrm{CO}_{2}$-e emissions of the latter. Direct emissions from livestock in Australia have remained relatively stable since 1990 , fluctuating with stock numbers within a range of about $5 \mathrm{Mt} \mathrm{CO}_{2}-\mathrm{e} \cdot \mathrm{yr}^{-1}$ (Table 1). Of the emissions directly from livestock in 2005, feedlot cattle contributed only $2 \mathrm{Mt} \mathrm{CO}_{2}-\mathrm{e} \cdot \mathrm{yr}^{-1}$ or about $3 \%$ (National Greenhouse Gas Inventory Committee 2005).

Accountable emissions (methane and nitrous oxide) from savanna burning in Australia contribute about $6-8 \%$ of global $\mathrm{C}$ emissions from biomass burning (Meyer et al. 2008) but fluctuate considerably between years. Most of this variation is due to seasonal conditions rather than variations in humansourced ignitions. In particular, fires in arid and semiarid Australia can be very extensive following periods of high rainfall. The base year for the national GHG inventory, 1990, contributed relatively low emissions from savanna burning. It has been assumed that $\mathrm{C}$ stores in above- and belowground pools of regularly burnt savanna are at equilibrium and do not contribute to annual accountable GHG emissions (National Greenhouse Gas Inventory Committee 2005). However, these $\mathrm{C}$ pools may change considerably under different fire regimes and could make a substantial contribution to GHG fluxes from Australian savannas (Williams et al. 2004).

\section{MANAGEMENT OF LIVESTOCK EMISSIONS}

Enteric methane production in the digestive tract of ruminants is a central process in the disposal of rumen hydrogen but constitutes both a loss of digested energy and a major source of agricultural GHG emissions (Alford et al. 2006). Ruminant livestock are the largest producers of methane in Australia, and the livestock industry has higher emissions per unit of gross domestic product than most other sectors (Howden and Reyenga 1999). Hence the livestock sector is likely to come under pressure to reduce emissions.

There are few practical strategies to reduce daily emissions from individual grazing animals without compromising their productivity, because methane production is highly dependent on the quantity of feed consumed (Hegarty et al. 2007). However, for cattle, genetic variation in the feed intake required for the same level of production or residual feed 
Table 2. The effect on methane emissions from a $30-\mathrm{kg}$ sheep of increasing forage digestibility when the protein content of that forage was held constant. ${ }^{1}$

\begin{tabular}{ccc}
\hline $\begin{array}{c}\text { Forage digestibility } \\
(\%)\end{array}$ & $\begin{array}{c}\text { Methane emission } \\
\text { (g methane per day) }\end{array}$ & $\begin{array}{c}\text { Emission intensity } \\
\text { (g methane per } \mathrm{g} \\
\text { liveweight gain) }\end{array}$ \\
\hline 55 & 24.5 & 4.9 \\
65 & 32.4 & 0.6 \\
75 & 35.4 & 0.2 \\
\hline
\end{tabular}

${ }^{1}$ Source: Hegarty (2001).

intake (RFI) can be exploited. Breeding for low RFI offers a commercially attractive and practical abatement technology because it does not demand reductions in livestock numbers or level of production. Conversion of the Australian cattle herd over $25 \mathrm{yr}$ could result in a $3.1 \%$ reduction in annual emissions of methane from cattle (Alford et al. 2006). Breeding and other anti-methanogen technologies, biological control of methanogens, or control of rumen protozoa (Klieve and Hegarty 1999) could provide rangeland industries with income under a cap and trading system for emissions through the sale of emissions permits (Howden and Reyenga 1999).

Manipulation of feed quality provides another method to manage methane emissions from livestock. With increasing digestibility of fodder and hence feed intake, the daily methane emissions per animal increase, but because the liveweight gain increases much faster, the methane emissions per unit production decrease sharply (Table 2 ). In rangelands the improvement of pasture quality will therefore increase annual enteric methane emissions per animal, but should also greatly increase farm gross margins and decrease the financial risk by decreasing interannual variability in gross margins (Alcock and Hegarty 2006). However, increased stock growth rates and reduced age of turnoff provide the potential to reduce stock numbers and therefore reduce emissions for the same level of meat production as is currently achieved.

The North Australian Pastoral Company (NAPCO) is one example of a company that has aimed to reduce its greenhouse emissions intensity (Bentley et al. 2008). It has improved herd genetics, property infrastructure, the seasonal feed base, and its utilization, as well as promoted feedlot finishing to reduce the number of unproductive animals and reduce age at slaughter. This improved management has reduced the GHG emissions per unit of liveweight gain across the whole herd. For example, in 1981 the emissions intensity of cattle on Alexandria Station was estimated to be $1.25 \mathrm{t} \mathrm{CH} \mathrm{CH}_{4} \cdot \mathrm{t}^{-1}$ liveweight weaned compared with 0.86 in 2006. When combined with other strategies such as use of solar energy systems, establishment of introduced perennial pastures, and minimum tillage, production and operational gains have been made along with further reductions in emissions intensity. NAPCO's property portfolio includes 14 cattle stations encompassing an area of approximately 6 million ha running approximately 190000 cattle, so clearly such innovations can contribute substantially to reducing the $\mathrm{C}$ intensity of the industry at a national scale. However, if the reduced $\mathrm{C}$ intensity is offset by increased stock numbers, then there will be no net benefit in terms of reduced GHG emissions.
Focusing on minimizing emissions per area of land under livestock production rather than on emissions per head is likely to result in a better alignment with sustainable land management practices than focusing only on emissions per head (Howden and Reyenga 1999). For example, conservative stocking and the maintenance of good pasture condition can maintain soil organic $\mathrm{C}$ and offset $\mathrm{CO}_{2}$-e emissions potentially an order of magnitude greater than those directly from the livestock (Ash et al. 1995), while improving sustainability of pastoral enterprises (Ash et al. 1997). Thus regardless of the emissions per animal, management of their impacts on land condition is likely to have the greatest long-term benefit.

Over two-thirds of the nation's nitrous oxide emissions derive from the Australian agriculture sector as defined under the national inventory, with about half of that coming from livestock and savanna burning (National Greenhouse Gas Inventory Committee 2005). Unlike methane emissions from livestock, which are produced mainly from the process of enteric fermentation, nitrous oxide emissions from livestock derive overwhelmingly from the deposition of feces and urine on soils (Dalal et al. 2003). The Australian greenhouse inventory, however, accounts for nitrous oxide emissions only from feedlot livestock and not from free-range grazing (Hegarty 2001). The uncertainties in these nitrous oxide emissions are high, but their contribution is small compared with that from methane, and there are few options to manage them except through manipulation of stock numbers. As with methane emissions, focusing on emissions per unit area is likely to produce the greatest overall benefit. Where fertilized exotic pastures have been established, substantial emissions of nitrous oxide from the activities of soil microorganisms during nitrification and denitrification are likely (Dalal et al. 2003).

\section{MANAGEMENT OF SAVANNA BURNING}

Savanna fires are pervasive across northern Australia (Andersen et al. 2003; Russell-Smith et al. 2003a, 2003c, 2007). Tens of millions of hectares are burnt each year, and this burning accounts for about $1-3 \%$ of Australia's GHG emissions. For the Northern Territory with a land area of 1.4 million $\mathrm{km}^{2}$, savanna burning accounts for about $40-50 \%$ of accountable emissions of methane and nitrous oxide (Environment Protection Agency Northern Territory 2006; National Greenhouse Gas Inventory Committee 2007).

In Australia savanna burning mostly occurs in the northwest, north, and center of the continent in regions where there is a fairly continuous grassy layer and human and livestock densities are low. Much of the land contributing to savanna burning emissions is indigenous-owned under a variety of tenures. The high fire frequency in this region is of concern not only for GHG emissions, but also for biodiversity conservation (Russell-Smith et al. 1998; Andersen et al. 2003; Woinarski et al. 2004; Whitehead et al. 2005). Improved management of the fires should bring benefits through reduced GHG emissions and improved wildlife habitat. Importantly, on indigenous land improved fire management that leads to greenhouse benefits will also lead to enhanced biodiversity conservation, substantial opportunities for employment, and improvements in skills, training, and organizational capacity for indigenous people in culturally appropriate activities 
in a region where few such opportunities exist (Russell-Smith et al. 2004; Gorman et al. 2007).

In the tropical savannas that contribute most to savanna burning, fuel decomposition rates are high. In these mesic savannas, equilibrium fine fuel loads are of the order of 5-10 t biomass $\cdot \mathrm{ha}^{-1}$ and are dominated by annual grasses and leaf litter from trees. Equilibrium fuel loads are reached within 3-5 yr (Cook 2003). Thus, reducing fire frequency from 1 in $2 \mathrm{yr}$ to 1 in $4 \mathrm{yr}$, for example, does not result in twice as much fuel being burnt half as often; reductions in fire frequency do lead to reduced average fuel combustion, increased residence time of $\mathrm{C}$ and nitrogen in the environment, and reduced GHG emissions. Consumption of methane by methanotrophic bacteria in the soils is an important sink for atmospheric methane (Dalal and Allen 2008). Thus any emissions of methane from the decomposition of fuel either by microorganisms or from consumption by termites are quickly absorbed and metabolized by methanotrophs (Arndt et al. 2007).

Commercial funding has supported reductions in fire frequency across broad landscapes at the scale of thousands of square kilometers as part of the Western Arnhem Land Fire Abatement Project (http://savanna.cdu.edu.au/information/arnhem fire_project.html). This has been achieved through the strategic use of early dry-season fires to manage the load and continuity of fuels and take advantage of natural barriers to fire spread across the landscape. Both on-ground and aerial control burns are implemented, and a two-tool-box approach to incorporating both western science and traditional knowledge (Yibarbuk et al. 2001; Russell-Smith et al. 2009) has been adopted. The project has facilitated renewed involvement of indigenous elders with the management of lands for which they are responsible and the engagement of younger generations in learning both traditional and new approaches to land management.

Unlike options to manage terrestrial C stocks, programs to reduce emissions of methane and nitrous oxide from savanna burning by reducing fire frequency can be effective indefinitely and do not have the risks of loss associated with forests (Girod and Hurtt 2007), nor will they saturate and cease to be effective in reducing GHG levels. Further, there are additional greenhouse benefits from the reductions in savanna burning in addition to the reductions in methane and nitrous oxide emissions. These are currently unaccounted and include the increased $\mathrm{C}$ sequestration under a more benign fire regime and reductions in the emissions of ozone precursors and $\mathrm{CO}_{2}$ from fires (Hurst et al. 1994; Williams et al. 2004; Chen et al. 2005; Beringer et al. 2007; Russell-Smith et al. 2007).

Under the 1996 Intergovernmental Panel on Climate Change (IPCC) guidelines for inventories, the default assumption was that savanna burning produced no net $\mathrm{CO}_{2}$ emissions (IPCC 1996). It was assumed that $\mathrm{CO}_{2}$ produced by savanna burning during the dry season is reabsorbed by plant growth in the following wet season and therefore does not alter $\mathrm{C}$ stocks. Thus only the nitrous oxide and methane emissions were accounted under savanna burning. Nevertheless, there was an allowance in the guidelines for calculation of $\mathrm{C}$ losses under severe fire regimes that degrade savannas, but such calculations were not pursued in the Australian inventory. The 2006 IPCC guidelines for grasslands and for forests allow incorporation of both increases and decreases in live and dead $\mathrm{C}$ stocks as a result of management practices. These changes in accounting rules have significant implications, which are discussed below.

\section{MANAGEMENT OF TERRESTRIAL CARBON STOCKS}

Worldwide, the storage of C on land as a GHG abatement strategy is controversial because of 1 ) difficulty in measurement and verification, 2) the vulnerability of terrestrial stocks to deforestation, fire, disease, and climate change, 3) the potential for diversion from the main goal of reduction in fossil fuel emissions, 4) difficulty in partitioning fortuitous from actively managed $\mathrm{C}$ sequestration, and 5 ) the likelihood that terrestrial sinks will reduce or saturate and become net sources in the latter half of the 21st century (Noble and Scholes 2001; Scholes and Noble 2001; Canadell et al. 2007a, 2007b; Girod and Hurtt 2007).

In Australia's rangelands, debate about terrestrial C stocks has been no less controversial than on the global scale and has centered on three main issues: 1) reduction in deforestation, 2) attribution of causes of and benefits from vegetation thickening, and 3) soil $\mathrm{C}$ sequestration.

\section{Reduction in Deforestation}

By the 1990s concerns about the environmental sustainability of land-clearing practices and the effects on Australia's C flux led to governments discouraging further deforestation. Reductions in rates of deforestation have the greatest immediate potential to reduce emissions across Australia's rangelands. Since 1990 the annual emissions caused by deforestation have fallen by more than $70 \mathrm{Mt} \mathrm{CO}_{2}-\mathrm{e} \cdot \mathrm{yr}^{-1}$ (Table 1). These emissions reductions make substantial contributions to Australia's total GHG budget, but the loss of the potential production gains that can be derived from land clearing in many areas remains controversial (Rolfe et al. 2000; Climate Institute 2006). The high levels of pasture productivity immediately after clearing are often assumed to persist in cost-benefit analyses but cannot usually be sustained (Myers and Robbins 1991; Schmidt and Lamble 2002). Unfertilized grass-only pastures such as green panic (Panicum maximum var. trichoglume) and buffel grass (Cenchrus ciliaris) sown on the Brigalow clays are initially highly productive but deteriorate markedly after 3-8 yr of grazing by beef cattle, with reductions in the dry matter yield, $\mathrm{N}$ yield, digestibility of the pasture, and cattle liveweight gain (Robertson et al. 1997). As well, after the initial boost to soil fertility after clearing, soil fertility declines, and soil salinity and sodicity often increase (Williams 1991; Williams and Chartres 1991; Kaur et al. 2007).

\section{Vegetation Thickening}

In common with many of the world's rangelands, increasing tree density or vegetation thickening has been observed in many parts of Australian rangelands (Burrows et al. 2002; Fensham et al. 2005; Krull et al. 2005). As well as vegetation thickening of relatively intact woodlands, regrowth of previously cleared woodland also contributes to $\mathrm{C}$ sinks. If atmospheric $\mathrm{CO}_{2}$ levels and land management practices were not changing, it would be expected that the gradual gains of $\mathrm{C}$ within terrestrial ecosystems would balance the rapid losses over large regions and long periods. However, rising atmospheric $\mathrm{CO}_{2}$ levels have resulted in most terrestrial ecosystems being net sinks, and 
recent evidence points to tropical terrestrial ecosystems generally being stronger $\mathrm{C}$ sinks than had been believed previously (Baker 2007; Stephens et al. 2007), although this remains controversial. Nevertheless, responsiveness to $\mathrm{CO}_{2}$ fertilization can be expected to be spatially heterogeneous with the least proportional change under nutrient- and especially nitrogen-limited and well-watered conditions, and the greatest proportional change under fertile water-limited conditions (Canadell et al. 2007a). In the mesic tropical savannas of Australia's Northern Territory, a range of assessment methodologies suggest that the sink strength under moderate fire regimes is about $1 \mathrm{t} \mathrm{C} \cdot \mathrm{ha}^{-1} \cdot \mathrm{yr}^{-1}$ (Williams et al. 2004; Beringer et al. 2007), whereas in semiarid Queensland the mean annual sink strength has been estimated at $0.53 \mathrm{t}$ $\mathrm{C} \cdot \mathrm{ha}^{-1} \cdot \mathrm{yr}^{-1}$ (Burrows et al. 2002). Thus, the full C budget of savannas is sensitive to rainfall and fire regime, and savanna fires are not $\mathrm{C}$ neutral as previously assumed (Cook et al. 2005; Beringer et al. 2007).

Changing climate and land management regimes will alter the frequency, type, and intensity of disturbance to the savanna C cycle, because of factors such as herbivory, drought, windthrow, and fires. Regional scale sinks or sources can result from such changes (Canadell et al. 2007a). In Queensland vegetation thickening has been attributed to pastoral land management and the consequent reduction in fire frequency (Burrows et al. 1988). Williams et al. (2004) argued that the sink strength of the tropical mesic savannas could be enhanced through changing to a more benign fire regime. In effect, these authors are arguing that savanna tree and shrub productivity is constrained by a fire and a competition trap under frequent fires through a restricted ability of juvenile trees to escape the understory and become canopy trees. The corollary is that reduction in severity of the fire regimes through direct management or through commercial livestock management can release juvenile savanna trees from this trap and thereby increase tree density in the canopy. Low atmospheric $\mathrm{CO}_{2}$ could have limited tree establishment during glacial times because the slower growth under low $\mathrm{CO}_{2}$ would have reduced their ability to recover after disturbance events, especially fire (Bond et al. 2003). By the same argument, some of the thickening observed in Australian savannas could be the result of enhanced ability of $\mathrm{C} 3$ trees to respond to disturbances as a result of $\mathrm{CO}_{2}$ fertilization, with this growth response larger than that from the $\mathrm{C} 4$ grassy component.

However, most vegetation across the world is thickening most of the time as it gradually recovers from relatively rapid effects of infrequent disturbances (Gifford and Howden 2001). Consistent with this hypothesis, the evidence for vegetation thickening in the semiarid savannas of Queensland has been questioned, and recovery from infrequent droughts has been invoked as an explanation for where it does occur (Fensham and Holman 1999; Fensham et al. 2005). In the mesic savannas of the Northern Territory, the observed increases are often in areas that have been subject to frequent cyclones (Murphy 1984; Cook and Goyens 2008), and recovery from windthrow could account for some of the observed $\mathrm{C}$ sequestration.

\section{Soil Carbon Sequestration}

Soil C concentrations in Australia's rangelands and savannas are lower than coastal tall, wet forests; however, their contribution to continental soil C stores are considerable because of their large land area (Webb 2002). The total store of $\mathrm{C}$ to $1 \mathrm{~m}$ depth in rangeland and savanna soils across $70 \%$ of the Australian land mass may be up to $48 \mathrm{Gt} \mathrm{C}$ (Baker et al. 2000). Land clearing, overstocking of grazing lands, and altered fire regimes all have the potential to increase soil C emissions from rangelands and savannas. For example, clearing of 1.3 Mha of mulga (Acacia aneura) vegetation for pasture production in Queensland is estimated to have resulted in at least $12 \mathrm{Mt} \mathrm{CO}_{2}$-e emissions from the soil (Dalal et al. 2005). In a larger study, Harms and Dalal (2003) observed a mean decline of $7.9 \%$ in soil C stocks to $0.3-\mathrm{m}$ depth after clearing of Acacia and Eucalyptus woodlands and savanna for cattle grazing in Queensland. A loss in soil C of this magnitude equates to roughly $260 \mathrm{Mt} \mathrm{CO}_{2}$-e emissions based on 1997 rates of vegetation clearing in Queensland (National Land and Water Resources Audit 2001).

Besides soil $\mathrm{C}$ emissions associated with initial clearing of rangelands for grazing, further soil C losses can result from grazing management of both cleared and uncleared rangelands. Soil C losses occur following degradation in soil structure, erosion, and reduction and modification of plant cover associated with heavy grazing by sheep, cattle, and feral animals (Ash et al. 1995; Baker et al. 2000; Dalal and Carter 2000; Northup et al. 2005). Studies of degraded and degrading experimental grazing treatments resulting from high stocking densities found a $30 \%$ reduction in soil C levels compared to control sites due to lower nutrient capture and microbial biomass around grass tussocks (Northup et al. 1999, 2005). Excessive grazing of aboveground plant cover can also cause a shift in species composition from perennial to annual grasses, which can reduce soil $\mathrm{C}$ inputs due to changes in root production and turnover (Ash et al. 1995). Interactions between stocking rates and variable rainfall also impact soil $\mathrm{C}$ emissions from grazed rangelands. Scenario analysis models predict that at stocking densities equivalent to $100 \%$ of 1997 levels, in combination with long-term patterns of drought, there is a $40 \%$ risk of significant soil C losses from Australia's grazed rangelands resulting in emissions of 730 to $1470 \mathrm{Mt}$ $\mathrm{CO}_{2}$-e in any 5-yr period (Hill et al. 2005, 2006). Recent reductions in rates of land clearing for pasture production in Queensland, as well as a better understanding of more sustainable grazing land management practices, could offer opportunities for increasing soil $\mathrm{C}$ sequestration and reducing GHG emissions from rangelands and savannas.

Soil C in mesic (>1200 mm annual rainfall), frequently burnt, intact savannas typically accounts for up to $150 \mathrm{t}$ $\mathrm{C} \cdot \mathrm{ha}^{-1}$ (Chen et al. 2003; Cook and Goyens 2008). However, changes to traditional fire regimes in Australia's northern savannas to more frequent and intense fires, or removal of fire, may result in a loss of soil C. For example, through reductions in fire frequency from a probability of $0.5 \cdot \mathrm{yr}^{-1}$ to a probability of $0.25 \cdot \mathrm{yr}^{-1}$, C sequestration as measured by net biome productivity was predicted to increase by about $0.25 \mathrm{t}$ $\mathrm{C} \cdot \mathrm{ha}^{-1} \cdot \mathrm{yr}^{-1}$ (Williams et al. 2004). The potential C sequestration through such changes in fire management represents a substantial increase in emissions abatement above reductions in accountable methane and nitrous oxide emissions. Much of the sequestered $\mathrm{C}$ would go into tree stem growth and shrub infilling (Cook et al. 2005; Beringer et al. 
Table 3. Options for reducing greenhouse gas (GHG) emissions and conditions under which there could be synergistic environmental and/or economic benefits. "One-off" GHG benefits provide a net benefit in GHG fluxes from rangelands only while the pool of sequestered C is increasing and if it is subsequently maintained.

\begin{tabular}{lcl}
\hline \multicolumn{1}{c}{ Option } & Benefit period & \multicolumn{1}{c}{ Conditions for environmental/economic synergies } \\
\hline $\begin{array}{l}\text { Reducing savanna burning } \\
\text { Reducing methane emissions }\end{array}$ & Ongoing & Ongoing \\
& & $\begin{array}{l}\text { Altered management in areas that are currently burned too frequently } \\
\text { Reduce overstocking } \\
\text { Improved herd management } \\
\text { Genetic engineering } \\
\text { Manipulation of rumen function }\end{array}$ \\
& & $\begin{array}{l}\text { Switch to nonruminants } \\
\text { Actively or passively revegetating cleared land }\end{array}$ \\
Woody C sequestration & One-off & Thickening of "overburned" vegetation \\
Soil C sequestration & & Harvesting of wood \\
\hline
\end{tabular}

2007) and probably soil C storage (Chen et al. 2005). Uncertainties lie in the likely duration of this savanna $\mathrm{C}$ sink and losses of $\mathrm{C}$ via dissolved inorganic and organic $\mathrm{C}$ compounds and volatile organic compounds.

Complete removal of fire from mesic savanna, however, may also result in soil $\mathrm{C}$ emissions. A study comparing soil $\mathrm{C}$ content in frequently burnt tropical savanna and a site where fire was excluded for 15-20 yr found lower soil C levels in the fire exclusion site, possibly because of lower grass $\mathrm{C}$ inputs (Chen et al. 2005). Removal of burning may also reduce the input of charcoal to the soil, which is a significant long-term store of C. Graetz and Skjemstad (2003) suggest that extensive burning in Australia's tropical grasslands produces a large charcoal sink that sequesters $\mathrm{C}$ into the soil at a rate of $21 \mathrm{Mt}$ $\mathrm{CO}_{2}-\mathrm{e} \cdot \mathrm{yr}^{-1}$.

\section{NATURAL RESOURCE MANAGEMENT SYNERGIES AND CONFLICTS}

In rangelands, trade-offs, particularly as a result of the potential for grass production to decrease with increasing tree cover, need to be acknowledged and balanced in land management decisions. Increased tree density, while potentially increasing $\mathrm{C}$ stocks, may also alter catchment hydrology and fauna, but where synergies exist between $C$ sequestration and other land management objectives (e.g., improved pasture condition, reduced soil erosion, and biodiversity conservation), it would be desirable to promote these combined benefits through existing natural resource management initiatives.

We consider four possible opportunities for altering the GHG balance of rangelands: reduced fire frequency, reduced livestock methane emissions, sequestration of $\mathrm{C}$ in woody $\mathrm{C}$ stores, and sequestration of $\mathrm{C}$ in soils (Table 3).

Reduced burning in rangelands, particularly savannas where pastoralism is a minor land use, would reduce methane and nitrous oxide emissions on an ongoing basis. In regions where fires are so frequent at present that they are ecologically damaging, reduced use of fire would have both emissions abatement and ecological benefits. However, in many savannas that are currently used for pastoralism, fire has been suppressed, with undesirable shifts to woodier vegetation at the expense of forage production (Dyer et al. 2001). This potential trade-off in land production would mean that reduced burning is most likely to be a viable option mainly in those rangelands that are burned too frequently at present.

As has been discussed above, methane production from livestock constitutes one of the major sources of greenhouse emissions from rangelands. Reduced emissions of methane from ruminant livestock would reduce GHG emissions on an ongoing basis. In areas that are currently overstocked, reducing stocking rates could have benefits for methane emissions, land condition, and enterprise sustainability. One of the contributors to high methane emissions from extensive cattle operations is the relatively poor diet qualities and associated poor dietary efficiency. Improvements to grazing management, herd management, diet supplements, and livestock genetics all could increase the nutritional efficiency of ruminant livestock with both GHG and animal production benefits provided that these gains are not countered by increased stock numbers. In addition, substituting ruminant livestock with nonruminants, such as native macropods, could reduce methane emissions.

Managing rangelands for increased stores of woody $\mathrm{C}$ would provide a temporary net flux of $\mathrm{C}$ into vegetation while stores of $\mathrm{C}$ were increasing. However, once woody stores reach a stable equilibrium, there would be no further benefit in net GHG fluxes. Saturation may occur within a few decades, after which other limiting factors such as water or phosphorus would reduce sink strength (Canadell et al. 2007b). Furthermore, the increased stores of woody $\mathrm{C}$ would have to be maintained in perpetuity to prevent future net $\mathrm{C}$ emissions that would accompany any decline in woody C pools. Since increases in tree abundance usually occur at the expense of grass production, the short-term benefit from $\mathrm{C}$ sequestration would have to be balanced against the continual loss in forage production each year thereafter. However, there are situations in which $\mathrm{C}$ sequestration in woody vegetation could pose an attractive opportunity. For example, on land that has been previously cleared of trees, the cost of restoring tree cover needs to be evaluated in the context of the cost to forage production. Where regrowth of cleared woodlands occurs naturally, there can be considerable costs (chemical and/or mechanical clearing) in maintaining a cleared landscape for pastoral production, and so managing some of these landscapes specifically for C sequestration may be a viable land use alternative. Carbon could be sequestered in such cases by reestablishing woody 
vegetation, with little long-term impact on the profitability of grazing operations. It may also be possible to strategically establish plantations of trees on portions that do not provide significant forage resources or that are inaccessible to livestock. In addition, where savannas are currently burned too frequent$l y$, reduced fire frequencies would not only reduce methane and nitrous oxide emissions but would also allow ecological recovery, including recovery of woody vegetation and woody $\mathrm{C}$ stores. The ability to maintain increased woody stores of $\mathrm{C}$ in the long term is an important consideration for sequestration of woody $\mathrm{C}$ in rangelands. Enhanced stores of $\mathrm{C}$ would be vulnerable to future changes in climate, fire regimes, and land management, with any declines in $\mathrm{C}$ stores contributing to GHG emissions from rangelands, reversing previous benefits. Moreover, there would be opportunity costs associated with C sequestration because maintaining $\mathrm{C}$ stores could limit future potential uses of land on which the enhanced $\mathrm{C}$ stores had to be maintained.

Managing rangelands for increased stores of soil C would provide a temporary net flux of $\mathrm{C}$ into soils while stores of $\mathrm{C}$ were increasing. In many rangelands where grazing has had negative environmental impacts, degradation has been accompanied by a decline in soil C stores. Restoring such degraded land would have environmental benefits while increasing $\mathrm{C}$ stores and improving the productive capacity of the land. In a recent report Garnaut (2008) suggests that improved soil management in Australia's grazing lands, through implementation of sustainable stocking rates, rotational grazing, and seasonal use grazing practices, may have the potential to remove $286 \mathrm{Mt} \mathrm{CO}_{2}$-e from the atmosphere per year for 20 $50 \mathrm{yr}$. However, in severely degraded land, such as areas where topsoil has been lost, there may be little opportunity for recovery in management time frames. The potential for soil C sequestration is therefore likely to be greatest in moderately degraded land where changes are not yet irreversible (Ash et al. 1995, 1997; Ludwig et al. 2001). Recent $\mathrm{CO}_{2}$ flux measurements from savanna vegetation subjected to low-intensity grazing on native grasses in the Daly River region suggests that this region is a net sink for C (L. B. Hutley, unpublished data, 2008).

If rangelands are managed with narrowly defined GHG objectives, then there are likely to be unintended negative environmental and economic consequences for grazing enterprises in the long term. A comprehensive assessment is required to fully explore the trade-offs between GHG objectives and broader natural resource management objectives. We have identified several opportunities where there could be the potential to achieve both positive GHG outcomes and broader benefits for grazing enterprises (Table 3). Where these synergies exist they should be highlighted and promoted through existing natural resource management initiatives.

\section{IMPLICATIONS}

Rangelands and savannas occupy most of the Australian continent. The two main land management practices that affect accountable GHG balance across this region are land clearing and savanna burning. For land clearing the National Greenhouse Gas Inventory attempts to undertake a full GHG account, including burning emissions of carbon dioxide, methane, and nitrous oxide as well as changes in soil $\mathrm{C}$ storage. In contrast, the approach to savanna burning represents a partial account that considers only the impact of fire management on emissions of methane and nitrous oxide. Given the very well-documented impacts of fire management on vegetation and C dynamics in savannas (Dyer et al. 2001; Russell-Smith et al. 2003b; Chen et al. 2005; Liedloff and Cook 2007), this inconsistency is leading to insufficient recognition of the potential to improve greenhouse outcomes through better fire management across much of the continent, particularly in the north. Research is needed to better develop more robust accounts of the impact of fire management on terrestrial C, but recognition of the considerable opportunities should stimulate investment in the development of appropriate verification methodologies.

Improved management of livestock has the potential to greatly reduce the emissions of GHGs per unit of production. For the best outcomes, such approaches must take full account of the effects of livestock management practices on terrestrial C stocks, particularly in the soil, as well as livestock emissions. Effective reductions in GHG emissions must focus on emissions per unit land area, rather than per beast. Such an approach is likely to lead to other benefits for land condition, such as improved biodiversity conservation and the maintenance of fertility and productive capacity.

\section{ACKNOWLEDGMENTS}

We thank Mary-Brooke McEachern, Scott Heckbert, and Melanie Bradley for helpful comments on the draft manuscript.

\section{LITERATURE CITED}

Alcock, D., and R. S. Hegarty. 2006. Effects of pasture improvement on productivity, gross margin and methane emissions of a grazing sheep enterprise. International Congress Series 1293:103-106.

Alford, A. R., R. S. Hegarty, P. F. Parnell, O. J. Сacho, R. M. Herd, and G. R. Griffith. 2006. The impact of breeding to reduce residual feed intake on enteric methane emissions from the Australian beef industry. Australian Journal of Experimental Agriculture 46:813-820.

Andersen, A. N., G. D. Cook, and R. J. Williams. 2003. Synthesis: fire ecology and adaptive conservation management. In: A. N. Andersen, G. D. Cook, and R. J. Williams [EDS.]. Fire in tropical savannas: the Kapalga experiment. New York, NY, USA: Springer. p. 153-164.

Arndt, S. K., S. J. Livesley, B. J. Fest, C. J. Weston, and K. Butterbach-Bahl. 2007. Methane uptake in forest and agro-ecosystems in Australia. American Geophysical Union 2007 Fall Meeting; 10-14 December 2007. San Francisco, CA, USA: American Geophysical Union.

Ash, A. J., S. M. Howden, AND J. G. Mclvor. 1995. Improved rangeland management and its implications for carbon sequestration. In: N. E. West [ED.]. Rangelands in a sustainable biosphere: proceedings of the 5th International Rangeland Congress; 23-28 July 1995. Salt Lake City, UT, USA: Society of Range Management. p. 19-20.

Ash, A. J., J. G. Mclvor, J. J. Motr, And M. H. Andrew. 1997. Building grass castles: integrating ecology and management of Australia's tropical tallgrass rangelands. Rangeland Journal 19:123-144.

Baker, B., G. Barnett, and M. Howden. 2000. Carbon sequestration in Australia's rangelands. In: R. Keenan, A. L. Bugg, and H. Ainslie [EDs.]. Management 
options for carbon sequestration in forest, agricultural and rangeland ecosystems: CRC for Greenhouse Accounting workshop proceedings; 25 May 2000. Canberra, Australia: CRC for Greenhouse Accounting. p. 73-82.

BAKER, D. F. 2007. Reassessing carbon sinks. Science 316:1708-1709.

Bentley, D., R. S. Hegarty, and A. R. Alford. 2008. Managing livestock enterprises in Australia's extensive rangelands for greenhouse gas and environmental outcomes: a pastoral company perspective. Australian Journal of Experimental Agriculture 48:60-64.

Beringer, J., L. B. Hutley, N. J. Tapper, and L. A. Cernusak. 2007. Savanna fires and their impact on net ecosystem productivity in North Australia. Global Change Biology 13:990-1004.

Bond, W. J., G. F. Midgley, and F. I. Woodward. 2003. The importance of low atmospheric $\mathrm{CO}_{2}$ and fire in promoting the spread of grasslands and savannas. Global Change Biology 9:973-982.

Bowman, D. M. J. S. 1998. The impact of Aboriginal landscape burning on the Australian biota. New Phytologist 140:385-410.

Burrows, W. H., B. K. Henry, P. V. Back, M. B. Hoffman, L. J. Tait, E. R. Anderson, N. Menke, T. Danaher, J. O. Carter, and G. M. McKeon. 2002. Growth and carbon stock change in eucalypt woodlands in northeast Australia: ecological and greenhouse sink implications. Global Change Biology 8:769-784.

Burrows, W. H., J. C. Scanlan, and M. T. Rutherford. 1988. Native pastures in Queensland-the resources and their management. Brisbane, Australia: Queensland Department of Primary Industries. 284 p.

Butler, B. E., and H. M. Churchward. 1983. Aeolian processes. In: CSIRO Division of Soils [ED.]. Soils: an Australian viewpoint. London, United Kingdom: Academic Press. p. 91-100.

Canadell, J. G., M. U. F. Kirschbaum, W. A. Kurz, M.-J. Sanz, B. Schlamadinger, and Y. YamagatA. 2007a. Factoring out natural and indirect human effects on terrestrial carbon sources and sinks. Environmental Science and Policy 10:370-384.

Canadell, J. G., D. E. Pataki, R. Gifford, R. A. Houghton, Y. Luo, M. R. Raupach, P. Smith, And W. StefFen. 2007b. Saturation of the terrestrial carbon sink. In: J. G. Canadell, D. E. Pitaki, and L. F. Pitelka [EDs.]. Terrestrial ecosystems in a changing world. Berlin, Germany: Springer-Verlag. p. 59-78.

Chen, X., L. B. Hutley, and D. Eamus. 2003. Carbon balance of a tropical savanna of northern Australia. Oecologia 137:405-416.

Chen, X., L. B. Hutley, and D. Eamus. 2005. Soil organic carbon content at a range of north Australian tropical savannas with contrasting site histories. Plant and Soil 268:161-171.

Climate Institute. 2006. Missing billions: how the Australian government's climate policy is penalising farmers. Sydney, Australia: Climate Institute. 12 p.

Cook, G. D. 2003. Fuel dynamics, nutrients and atmospheric chemistry. In: A. N. Andersen, G. D. Cook, and R. J. Williams [EDS.]. Fire in tropical savannas: the Kapalga experiment. New York, NY, USA: Springer. p. 47-58.

Cook, G. D., AND L. DiAS. 2006. It was no accident: deliberate plant introductions by Australian governments during the 20th century. Australian Journal of Botany 54:601-625.

Cook, G. D., AND C. M. A. C. Goyens. 2008. The impact of wind on trees in Australian tropical savannas: lessons from the impact of Cyclone Monica. Austral Ecology 33:462-470.

Cook, G. D., A. C. Liedloff, R. W. Eager, X. Chen, R. J. Williams, A. P. O’Grady, and L. B. HutLEY. 2005. The estimation of carbon budgets of frequently burnt tree stands in savannas of northern Australia using allometric analysis and isotopic discrimination. Australian Journal of Botany 53:621-630.

Dalal, R. C., and D. E. Allen. 2008. Greenhouse gas fluxes from natural ecosystems. Australian Journal of Botany 56:369-407.

Dalal, R. C., and J. O. Carter. 2000. Soil organic matter dynamics and carbon sequestration in Australian tropical soils. In: R. Lal, J. M. Kimble, and B. A. Stewart [EDS.]. Global climate change and tropical ecosystems. Boca Raton, FL, USA: CRC Press. p. 285-314.

Dalal, R. C., B. P. Harms, E. S. Krull, and W. J. Wang. 2005. Total soil organic matter and its labile pools following mulga (Acacia aneura) clearing for pasture development and cropping 1. Total and labile carbon. Australian Journal of Soil Research 43:13-20.
Dalal, R. C., W. Wang, G. P. Robertson, and W. J. Parton. 2003. Nitrous oxide emission from Australian agricultural lands and mitigation options: a review. Australian Journal of Soil Research 41:165-195.

Dyer, R., P. Jacklyn, I. Partridge, J. Russell-Smith, and R. J. Williams. 2001. Savanna burning: understanding and using fire in northern Australia. Darwin, Australia: Tropical Savannas CRC. $136 \mathrm{p}$.

Environment Protection Agency Northern TerRitory. 2006. Northern territory strategy for greenhouse action 2006. Palmerston, Australia: Northern Territory Government. 20 p.

Fensham, R. J., R. J. Fairfax, and S. R. Archer. 2005. Rainfall, land use and woody vegetation cover change in semi-arid Australian savannas. Journal of Ecology 93:596-606.

Fensham, R. J., And J. E. Holman. 1999. Temporal and spatial patterns in drought related tree dieback in Australian savannas. Journal of Applied Ecology 36:1035-1050.

Fisher, A., L. Hunt, C. James, J. Landsberg, D. Phelps, A. Smyth, and I. Watson. 2004. Review of total grazing pressure management issues and priorities for biodiversity conservation in rangelands: a resource to aid NRM planning. Alice Springs, Australia: Desert Knowledge CRC, A report to the Australian Government Department of Environment and Heritage prepared by the Desert Knowledge CRC and Tropical Savannas Management CRC. 163 p.

Garnaut, R. 2008. The garnaut climate change review final report. Melbourne, Australia: Cambridge University Press. 616 p.

GifFord, R., AND M. Howden. 2001. Vegetation thickening in an ecological perspective: significance to national greenhouse gas inventories. Environmental Science and Policy 4:59-72.

Girod, C. M., AND G. C. HuRTt. 2007. The tension between fire risk and carbon storage: evaluating U.S. carbon and fire management strategies through ecosystem models. Earth Interactions 11:1-33.

Gorman, J. T., R. J. Williams, J. J. Russell-Smith, L. Hutley L. and G. D. Cook. 2007. A case for indigenous fire management. In: M. K. Luckert, B. Campbell, J. T. Gorman, and S. T. Garnett [EDS.]. Investing in indigenous natural resources management. Darwin, Australia: Charles Darwin University Press. p. 22-30.

Graetz, R. D., and J. O. SkJemstad. 2003. The charcoal sink of biomass burning on the Australian continent. Aspendale, Australia: CSIRO, Atmospheric research technical paper no. 64. $61 \mathrm{p}$.

Graetz, R. D., B. H. Walker, and P. A. Walker. 1988. The consequences of climatic change for seventy percent of Australia. In: G. I. Pearman [ED.]. Greenhouse: planning for climate change. Melbourne, Australia: CSIR0. p. 399-420.

Harms, B. P., and R. C. Dalal. 2003. Paired site sampling for soil carbon (and nitrogen) estimation-Queensland. Canberra, Australia: National Carbon Accounting System technical report no. 37. 232 p.

Hegarty, R. S. 2001. Greenhouse gas emissions from the Australian livestock sector: what do we know, what can we do? Canberra, Australia: Australian Greenhouse Office, Greenhouse and Agriculture Taskforce report. 32 p.

Hegarty, R. S., J. P. Goopy, R. M. Herd, and B. McCorkell. 2007. Cattle selected for lower residual feed intake have reduced daily methane production. Journal of Animal Science 85:1479-1486.

Hill, M. J., S. H. Roxburgh, J. 0. Carter, and G. M. McKeon. 2005. Vegetation state change and consequent carbon dynamics in savanna woodlands of Australia in response to grazing, drought and fire: a scenario approach using 113 years of synthetic annual fire and grassland growth. Australian Journal of Botany 53:715-739.

Hill, M. J., S. H. Roxburgh, G. M. McKeon, J. O. Carter, and D. J. Barrett. 2006. Analysis of soil carbon outcomes from interaction between climate and grazing pressure in Australian rangelands using Range-ASSESS. Environmental Modelling and Software 21:779-801.

Howden, S. M., and P. J. Reyenga. 1999. Methane emissions from Australian livestock: implications of the Kyoto Protocol. Australian Journal of Agricultural Research 50:1285-1291.

Hurst, D. F., D. W. T. Griffith, And G. D. Cook. 1994. Trace gas emissions from biomass burning in tropical Australian savannas. Journal of Geophysical Research 99:16,441-16,456. 
[IPCC] Intergovernmental Panel on Climate Change. 1996. Revised 1996 IPCC guidelines for national greenhouse gas inventories: module 4-agriculture. London, United Kingdom: Intergovernmental Panel on Climate Change, $33 p$.

Kaur, K., R. K. Jalota, and D. J. Midmore. 2007. Impact of tree clearing on soil attributes for a pastoral property in central Queensland, Australia. Soil Science 172:516-533.

Klieve, A. V., and R. S. Hegarty. 1999. Opportunities for biological control of ruminal methanogenesis. Australian Journal of Agricultural Research 50:1315-1319.

Krull, E. S., J. 0. Skjemstadt, W. H. Burrows, S. G. Bray, J. G. Wynn, R. Bol, L. Spouncer, and B. Harms. 2005. Recent vegetation changes in central Queensland, Australia: evidence from $\delta^{13} \mathrm{C}$ and ${ }^{14} \mathrm{C}$ analyses of soil organic matter. Geoderma 126:241-259.

LIEDLOFF, A. C., AND G. D. Cook. 2007. Modelling the effects of rainfall variability and fire on tree populations in an Australian tropical savanna using the Flames simulation model. Ecological Modelling 201:269-282.

Linacre, E., and J. HobBs. 1977. The Australian climatic environment. Brisbane, Australia: John Wiley and Sons. $354 \mathrm{p}$.

Ludwig, J., D. Tongway, D. Freudenberger, J. C. Noble, and K. Hodgkinson. 1997. Landscape ecology function and management: principles from Australia's rangelands. Melbourne, Australia: CSIRO Publishing. 158 p.

Ludwig, J. A., M. B. Coughenour, A. C. Liedloff, And R. Dyer. 2001. Modelling the resilience of Australian savanna systems to grazing impacts. Environment International 27:167-172.

McKenzie, N. J., D. Jacquier, R. F. Isbell, and K. Brown. 2004. Australian soils and landscapes: an illustrated compendium. Collingwood, Australia: CSIRO Publishing. $416 \mathrm{p}$.

Meyer, C. P., A. K. Luhar, and R. M. Mitchell. 2008. Biomass burning emissions over northern Australia constrained by aerosol measurements: I-Modelling the distribution of hourly emissions. Atmospheric Environment 42:1629-1646.

Murphy, K. 1984. Big blow up north: a history of tropical cyclones in Australia's Northern Territory. Darwin, Australia: University Planning Authority. 94 p.

Myers, R. J. K., AND G. B. RobBins. 1991. Sustaining productive pastures in the tropics 5. Maintaining productive sown grass pastures. Tropical Grasslands 25:104-110.

National Greenhouse Gas Inventory Committee. 1994. National Greenhouse Gas Inventory 1988 and 1990. Canberra, Australia: Department of Environment, Sport and Territories. $269 \mathrm{p}$.

National Greenhouse Gas Inventory Committee. 2005. National Greenhouse Gas Inventory 2005. Canberra, Australia: National Greenhouse Gas Inventory Committee. 29 p.

National Greenhouse Gas Inventory Committee. 2007. State and Territory Greenhouse Gas Inventories 2005. Canberra, Australia: Australian Greenhouse Office, 33 p.

National Land and Water Resources Audit. 2001. Australian native vegetation assessment 2001. Available at: http://www.anra.gov.au/topics/vegetation/ pubs/native_vegetation/nat_veg_contents.html. Accessed 15 October 2008.

Noble, I., And R. J. Scholes. 2001. Sinks and the Kyoto Protocol. Climate Policy 1:5-25.

Northup, B. K., J. R. BRown, and A. J. Ash. 2005. Grazing impacts on spatial distribution of soil and herbaceous characteristics in an Australian tropical woodland. Agroforestry Systems 65:137-150.

Northup, B. K., J. R. Brown, AND J. A. Holt. 1999. Grazing impacts on the spatial distribution of soil microbial biomass around tussock grasses in a tropical grassland. Applied Soil Ecology 13:259-270.

Robertson, F. A., R. J. K. Myers, and P. G. Saffigna. 1997. Nitrogen cycling in Brigalow clay soils under pasture and cropping. Australian Journal of Soil Research 35:1323-1339.

Rolfe, J., J. Bennett, and R. Blamey. 2000. An economic evaluation of broadscale tree clearing in the Desert Uplands region of Queensland. Canberra, Australia: School of Economics and Management, University College, University of New South Wales, Choice modelling research report no. 12. 21 p.

Russell-Smith, J., A. C. Edwards, and G. D. Cook. 2003a. Reliability of biomass burning estimates from savanna fires: biomass burning in northern Australia during the 1999 Biomass Burning and Lightning Experiment B field campaign. Journal of Geophysical Research 108:1-12.
Russell-Smith, J., D. Lucas, M. Gapindi, B. Gunbunuka, N. Kapirigi, G. Namingum, K. LUCAS, P. GIULIANI, AND G. ChaloupKa. 2004. Aboriginal resource utilization and fire management practice in Western Arnhem Land, monsoonal Northern Australia: notes for prehistory, lessons for the future. Human Ecology 25:159-195.

Russell-Smith, J., B. P. Murphy, C. P. Meyer, G. D. Cook, S. Meier, A. C. Edwards, J. Schatz, AND P. BRocklehURST. 2009. Improving estimates of savanna burning emissions for greenhouse accounting in northern Australia: limitations, challenges, applications. International Journal of Wildland Fire 18:1-18.

Russell-Smith, J., P. G. Ryan, D. Klessa, G. Waight, and R. Harwood. 1998. Fire regimes, fire sensitive vegetation and fire management of the sandstone plateau, monsoonal northern Australia. Journal of Applied Ecology 35:829-846.

Russell-Smith, J., P. J. Whitehead, G. D. Cook, and J. L. Hoare. 2003b. Response of eucalyptus-dominated savanna to frequent fires: lessons from munmarlary, 1973-1996. Ecological Monographs 73:349-375.

Russell-Smith, J., C. Yates, A. Edwards, G. E. Allan, G. D. Cook, P. Cooke, R. Craig, B. Heath, and R. Smith. 2003c. Contemporary fire regimes of northern Australia, 1997-2001: change since Aboriginal occupancy, challenges for sustainable management. International Journal of Wildland Fire 12:283-297.

Russell-Smith, J., C. P. Yates, P. J. Whitehead, R. Smith, R. Craig, G. E. Allan, R. Thackway, I. Frakes, S. Cridland, M. C. P. Meyer, and A. M. Gilll. 2007. Bushfires 'down under': patterns and implications of contemporary Australian landscape burning. International Journal of Wildland Fire 16:361-377.

Schmidt, S., AND R. E. Lamble. 2002. Nutrient dynamics in Queensland savannas: implications for the sustainability of land clearing for pasture production. Rangeland Journal 24:96-111.

Scholes, R. J., and I. R. Noble. 2001. Storing carbon on land. Science 294:1012-1013

Stafford-Smith, D. M., and S. R. Morton. 1990. A framework for the ecology of arid Australia. Journal of Arid Environments 18:255-278.

Stephens, B. B., K. R. Gurney, P. P. Tans, C. Sweeney, E. Peters, L. Bruhwiler, P. Cials, M. Ramonet, P. Bousquet, T. Nakazawa, S. Aoki, T. Machida, G. Inoue, N. Vinnichenko, J. Lloyd, A. Jordan, M. Heimann, O. Shibistova, R. L. Langenfelds, L. P. Steele, R. J. Francey, and A. S. Denning. 2007. Weak northern and strong tropical land carbon uptake from vertical profiles of atmospheric $\mathrm{CO}_{2}$. Science 316:1732-1735.

TrewIN, D. 2007. Year book: Australia 2007. Canberra, Australia: Australian Bureau of Statistics. 745 p.

WeBB, A. 2002. Pre-clearing soil carbon levels in Australia. Canberra, Australia: National Carbon Accounting System, Technical report no. 12. 204 p.

Whitehead, P. J., J. Russell-Smith, and J. C. Z. Woinarski. 2005. Fire, landscape heterogeneity and wildlife management in Australia's tropical savannas: introduction and overview. Wildlife Research 32:369-375.

Wilııms, J. 1991. Search for sustainability: agriculture and its place in the natural ecosystem. Agricultural Science 4:32-39.

Williams, J., AND C. J. Chartres. 1991. Sustaining productive pastures in the tropics 1. Managing the soil resource. Tropical Grasslands 25:73-84.

Williams, R., G. Cook, R. Dyer, P. Jacklyn, I. Partridge, J. Russell-Smith, and R. Williams. 2001. Savanna landscapes. In: R. Dyer, P. Jacklyn, I. Partridge, J. Russell-Smith, and R. J. Williams [EDS.]. Savanna burning: understanding and using fire in northern Australia. Darwin, Australia: Tropical Savannas CRC. p. 5-14.

Williams, R. J., L. B. Hutley, G. D. Cook, J. Russell-Smith, A. Edwards, and X. Chen. 2004. Assessing the carbon sequestration potential of mesic savannas in the Northern Territory, Australia: approaches, uncertainties and potential impacts of fire. Functional Plant Biology 31:415-422.

WoInARSKI, J. C. Z., J. RisLeR, AND L. KeAn. 2004. The response of vegetation and vertebrate fauna to 23 years of fire exclusion in a tropical Eucalyptus open forest, Northern Territory, Australia. Austral Ecology 29:156-176.

Woinarski, J. C. Z., R. J. Williams, O. Price, and B. Rankmore. 2005. Landscapes without boundaries: wildlife and their environments in northern Australia. Wildlife Research 32:377-388.

Yibarbuk, D., P. J. Whitehead, J. Russell-Smith, D. Jackson, C. Godjuwa, A. Fisher, P. Cooke, D. Choquenot, and D. M. J. S. Bowman. 2001. Fire ecology and Aboriginal land management in central Arnhem Land, northern Australia: a tradition of ecosystem management. Journal of Biogeography 28:325-343. 